\title{
Influence of Dietary Moringa oleifera Leaf Meal on Haematological Parameters, Serum Biochemical Indices and Weight of Internal Organs of Chickens
}

\author{
NThabiseng. A. Sebola ${ }^{*}$, Hilda. K. MоковоKI ${ }^{2}$
}

${ }^{1}$ University of South Africa, Department of Agriculture and Animal Health, College of Agriculture and Environmental Sciences, Florida 1710, South Africa; ${ }^{2}$ Department of Animal Science, School of Agricultural Sciences, Faculty of Natural and Agricultural Sciences, North West University, Mmabatho 2735, Mafikeng, South Africa.

\begin{abstract}
A 90-day feeding trial was conducted to determine the effect of dietary Moringa oleifera leaf meal (MOLM) supplementation on blood indices and weight of internal organs of three indigenous chicken species. Moringa leaves were harvested by hand, air-dried and milled into M. oleifera leaf meal (MOLM). The leaf was chemically analysed and used to dilute a commercial broiler basal diet at 0 (MOLM0), 25 (MOLM25), 50 (MOLM50), and 100 (MOLM100) $\mathrm{g} / \mathrm{kg}$ DM, producing four isonitrogenous and isoenergetic dietary treatments. Two hundred and sixteen (216) Potchefstroom Koekoek (PK), Ovambo (OV) and Black Australorp (BA) male chickens were raised on a commercial starter mash for 3 weeks in a 3 (chicken strains) $\mathrm{x} 4$ (diets) factorial treatment arrangement in a complete randomised design (CRD) replicated 3 times. At 13 weeks of age, blood samples were taken from 6 chickens per treatment and used for biochemical and haematological analysis. Incremental levels of MOLM exhibited higher WBC than control diet (MOLM0). Higher inclusion levels of MOLM resulted in longer small intestines and heavier gizzards in all chicken strains. Low levels of ALT and ALKP were observed when chickens were fed incremental levels of MOLM. Inclusion of MOLM at levels up to $100 \mathrm{~g} / \mathrm{kg}$ had no adverse effects on health status of the chicken strains.
\end{abstract}

Keywords | Haematology, Moringa oleifera, Indigenous chickens, Internal organs, Serum biochemistry

\footnotetext{
Received | June 25, 2019; Accepted | August 19, 2019; Published | November 13, 2019

${ }^{*}$ Correspondence | Nthabiseng. A. Sebola, University of South Africa, Department of Agriculture and Animal Health, College of Agriculture and Environmental Sciences, Florida 1710, South Africa; Email: sebolan@unisa.ac.za

Citation | Sebola NA, Mokoboki HK (2019). Influence of dietary moringa oleifera leaf meal on haematological parameters, serum biochemical indices and weight of internal organs of chickens influence of dietary moringa oleifera leaf meal on haematological parameters, serum biochemical indices and weight of internal organs of chickens. Adv. Anim. Vet. Sci. 7(12): 1042-1048.

DOI | http://dx.doi.org/10.17582/journal.aavs/2019/7.12.1042.1048
}

ISSN (Online) | 2307-8316; ISSN (Print) | 2309-3331

Copyright $\odot 2019$ Sebola and Mokoboki. This is an open access article distributed under the Creative Commons Attribution License, which permits unrestricted use, distribution, and reproduction in any medium, provided the original work is properly cited.

\section{INTRODUCTION}

$\mathrm{P}$ oultry production plays an important socio-economic role in developing countries (Kondombo, 2005). However, the industry in the developing countries encounters constrains such as high costs of medicinal and feed ingredients (Abbas, 2013). Conventional poultry production has always been dependent on expensive protein and energy. These feedstuffs account for nearly $80 \%$ of the total costs of production (Nworgu and Fasogbon, 2007). The use of non-conventional feedstuff as alternative feed supplement with medicinal benefits especially to extensively reared chickens (indigenous) will be of great value. Uti- lization of plant leaf meals as alternative feed ingredients to conventional feed resources is gaining research interest in animal nutrition (Melesse et al., 2013). The medicinal plants having various phytochemical and bioactive components such as vitamins, carotenoids, polyphenols, and proteins are involved in enhancing long-term health benefits (Sravanthi and Rao, 2014). The use of natural medicinal products as feed additives for farm animals has been practised in ancient cultures (WHO 2001). Windisch and Kroismayr (2006) redefined phytobiotics as plant derived products added to the feed in order to improve performance of agricultural livestock. Antimicrobial activity and immune enhancement probably are the two major 
mechanisms by which phytobiotics exert positive effect on the growth performance and health of animals (Fallah et al., 2013). Plant based antimicrobials represent a vast untapped source of medicines with enormous therapeutic potential (Cowan, 1999). Furthermore, there has been an increased awareness of the potential that natural compounds have in the prevention and treatment of poultry diseases (Chen et al., 2003; Guo et al., 2003). Plants such as Nigella Sativa Linn was reported to be a significant source of essential nutritive substance and enhanced performance traits in broiler chickens (Attia and A1-Harthi, 2015; Attia et al., 2003; Attia et al, 2008; Essam et al., 2017). Also, Essam et al. (2017) reported that broilers fed 5.6\% N. Sativa Linn showed improved immune response and subsequent resistance against diseases. Furtherance, Yasser et al. (2014) observed a significantly enhanced immune response and blood profile of broilers fed 1:1 ratio of garlic and thyme. Similarly, plant like Moringa oleifera (MO) is known for both nutritional and medicinal properties. Moringa oleifera leaf is known for its high leaf protein (27\%) content, adequate amino acid profile, fatty acids, high level of vitamins $\mathrm{A}$ and $\mathrm{E}$, and low level of anti-nutritional compounds (Yang et al., 2006; Fuglie, 2001; Sebola et al., 2017). Vitamin $\mathrm{E}$ plays an important role in various biochemical and physiological processes, including antioxidant activity (Litta et al., 2014). Reportedly, the supplementation of 150 and $300 \mathrm{IU} / \mathrm{kg}$ vitamin $\mathrm{E}$ to feed was shown to improve the immune response and to reduce the mortality of chickens challenged with E. coli (Tengerdy and Nockels, 1976). Extensively reared chickens are scavengers and often raised without outlined vaccination programs, so this study will investigate the medicinal benefits of Moringa oleifera leave (MOL) on health parameters in chickens. Therefore, the study hypothesised that incremental levels of Moringa oleifera leaf meal will have an effect on the haematological, serum biochemical indices and internal organs of extensively reared chickens.

\section{MATERIALS AND METHODS}

This study was conducted at the North West University Experimental Farm (Molelwane), Mafikeng (25.8 ${ }^{\circ} \mathrm{S}$ and $25.5^{\circ} \mathrm{E}$ ), South Africa. Moringa oleifera leaves were obtained from Patience Wellness Centre in Limpopo Province $\left(24.305^{\circ} \mathrm{S} 29.565^{\circ} \mathrm{E}\right)$. The leaves were air-dried at a room temperature and then milled to pass through a 2 $\mathrm{mm}$ sieve. Four diets were constituted using $M$. oleifera leaf meal (MOLM) as follows: $100 \%$ basal mash (MOLM0); 97.5\% basal mash and 2.5\% MOLM (MOLM25); 5\% MOLM and 95\% basal mash (MOLM50); and 10\% MOLM and $90 \%$ basal mash (MOLM100). The composition of MOLM and experimental diets are presented in Table 1 for descriptive purposes. Experimental diets were formulated to be isonitrogenous and isoenergetic.
Two hundred and sixteen (216) male chickens from Potchefstroom Koekoek, Ovambo and Black Australorp strains were raised on a commercial starter mash for three weeks. At four weeks of age, the chickens from each breed were randomly allocated to the 4 experimental diets. A 3 (chicken strains) x 4 (diets) factorial treatment arrangement in a complete randomised design (CRD) was used for this experiment. The experimental unit was a pen holding 6 birds, which was replicated 4 times, resulting in a total of 36 floor pens (measuring $60 \times 50 \times 75 \mathrm{~cm}$ ). Feed and water were offered ad libitum during the 13 weeks. Continuous lightning was provided for first four weeks, which was then gradually decreased to that of natural day light. The study was conducted according to the guidelines of the ethics committee of North West University. All animal husbandry practices were performed with full consideration of animal welfare.

At the end of the 13-week feeding trial, blood samples were collected from all 6 birds in each feeding trial. About $2 \mathrm{ml}$ of blood was collected from each bird into two sets of sterilised bottles, one of them holding EDTA as anticoagulant and the other tube without. Haematological parameters (haemoglobin $(\mathrm{Hb} \mathrm{g} / \mathrm{L})$, red blood cells $\left(\mathrm{RBC} 10^{12} / \mathrm{L}\right)$, white blood cells (WBC10\%/L), haematocrit (HCT \%) and mean corpuscular haemoglobin $(\mathrm{MCH}$ pg) were determined using an automated Idexx Laser Cyte Haematology (IDEXX Laboratories, Inc) and the values were recorded in $\mathrm{g} / 100 \mathrm{ml}$. Mean corpuscular haemoglobin concentration (MCHC) was calculated as:

$$
M C H C=\frac{M C H}{M C V} \text {, where } \mathrm{MCH} \text { is mean corpuscular }
$$
haemoglobin and MCV is the mean corpuscular volume. Clotted blood (collected in red top tubes) was centrifuged in a macro centrifuge to generate serum for biochemical analysis. Total protein $(\mathrm{TP} g / \mathrm{L}), \mathrm{Urea}(\mathrm{mmol} / \mathrm{L})$, creatinine $(\mu \mathrm{mol} / \mathrm{L})$, albumin $(\mathrm{g} / \mathrm{L})$, serum cholesterol $(\mathrm{mmol} / \mathrm{L})$, aspartate transaminase (AST) $(\mathrm{U} / \mathrm{L})$, alanine transaminase (ALT) (U/L) and alkaline phosphate (ALKP) (U/L) were analysed using an automated Idexx Vet Test Chemistry Analyser (IDEXX Laboratories, Inc).

At 13 weeks of age, all chickens were electrically stunned and killed by manual exsanguination. Weights of the liver, gizzard (cleaned), heart, lungs, and pancreas as well as the length of small intestines were determined using a sensitive weighing balance and measuring tape $(\mathrm{cm})$, respectively.

Variation in organ size, haematological and serum biochemical indices data was analysed using SAS (2008) software according to the following general linear model:

$Y_{i j k}=\mu+S_{i}(i=1-2)+D_{j}(j=1-5)+(S \times D)_{i j}+E_{i j k}$

Where Yijk = dependent variable (organ size, haematolog 
Table 1: Gross composition of Moringa oleifera leaf meal (MOLM) based experimental diets

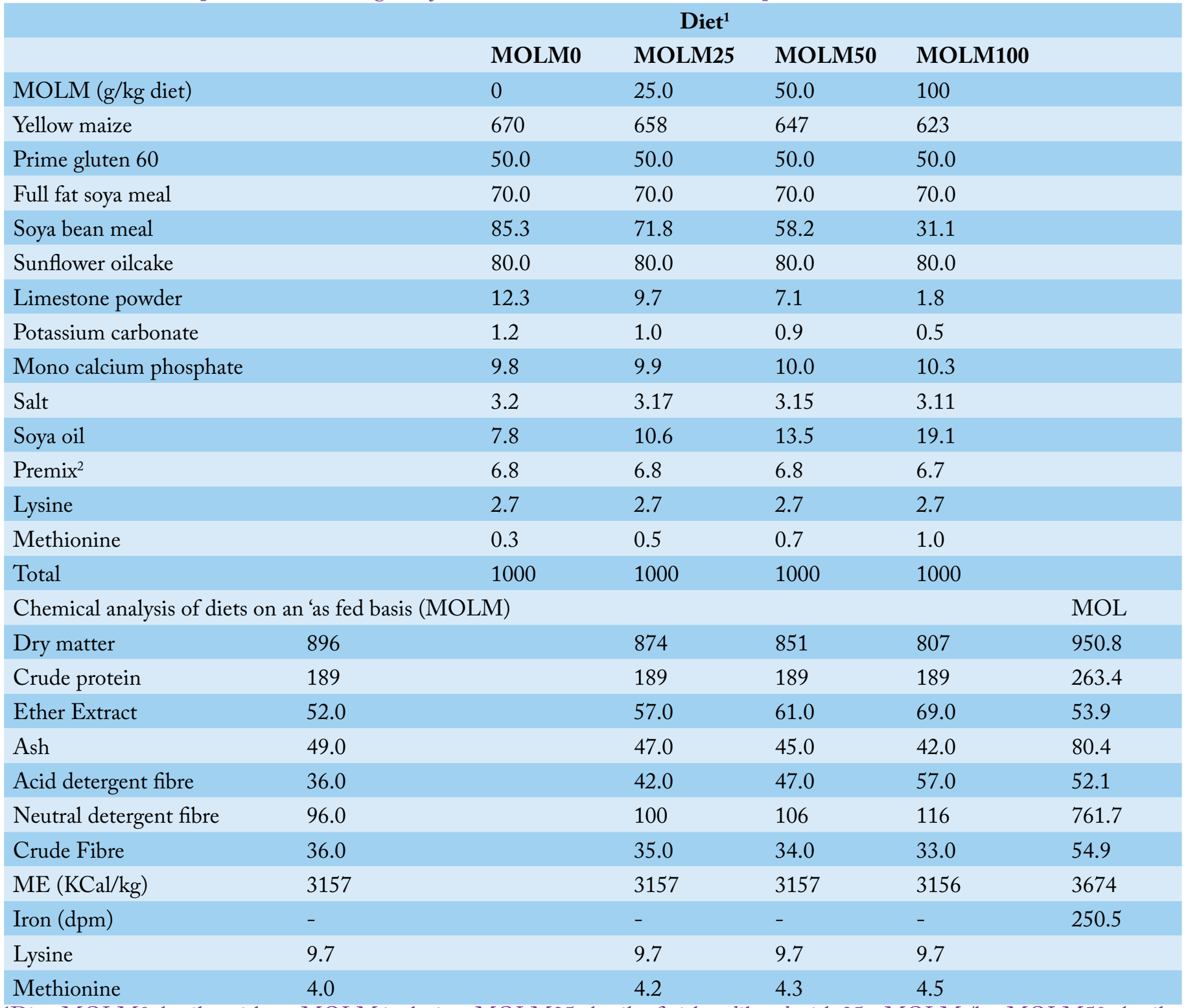

${ }^{1}$ Diet: MOLM0=broiler without MOLM inclusion; MOLM25= broiler finisher diluted with $25 \mathrm{~g}$ MOLM $/ \mathrm{kg}$; MOLM50= broiler finisher diluted with $50 \mathrm{~g}$ MOLM $/ \mathrm{kg}$; MOLM100= broiler finisher diluted at $100 \mathrm{~g}$ MOLM $/ \mathrm{kg}$. MOL = Moringa oleifera leaf Premix²: vitamin A, 40,000 IU; vitamin D3, 8,000 IU; vitamin E, 10 IU; vitamin K3, 4.0 mg; vitamin B1, 4.0 mg; vitamin B2, 12.0 $\mathrm{mg}$; vitamin B6, $6.0 \mathrm{mg}$; vitamin B12, $0.02 \mathrm{mg}$; niacin, $250 \mathrm{mg}$ choline; $60.0 \mathrm{mg}$; pantothenic acid, $20 \mathrm{mg}$; folic acid, $2.0 \mathrm{mg}$; biotin, 0.02 mg; Fe, 30.0 mg; Zn, 25.0 mg; 20.0 mg; Cu, 5.0 mg; Se, 0.1 mg

ical and serum biochemical indices), $\mu=$ overall mean, $\mathrm{Si}$ $=$ effect of bird strain level $\mathrm{i}, \mathrm{Dj}=$ effect of experimental diet level $\mathrm{j},(\mathrm{S} \times \mathrm{D}) \mathrm{ij}=$ interactive effect of bird strain and diet and Eijk = random error. The significance was declared when $p<0.05$. For parameters where significant variation was detected, multiple comparisons of treatment means were carried out using the probability of difference (pdiff) option of the General Linear Models (GLM) procedures of SAS.

\section{RESULTS AND DISCUSSION}

Statistical significance of the effects of main factors on haematology of chicken strains fed increasing levels of
MOLM are presented in Table 2. In the current study, haematological values of blood cells of the three different chicken strains were within the normal range similar to those reported by Jain (1993) in growing chickens. The results revealed that haematological values vary $(p<0.05)$ among chicken strains. Bilkovaa et al. (2017) reported a substantial variation between chicken breed on haematological parameters. Different strains responded differently to incremental levels of MOLM. The interaction term 'diet $x$ strain' did not $(p>0.05)$ affect RBC, Haematocrit, haemoglobin, $\mathrm{MCH}$, white blood cells, monocyetes and basophils in all chickens but significantly influenced $\mathrm{MCH}$, MCHC, Lymphocytes, Neutrophils and eosophils. Therefore, MOLM provided sufficient quality dietary iron and 
Table 2: Haematological parameters in 13-week old chickens fed incremental levels of Moringa oleifera leaf meal (MOLM).

\begin{tabular}{|c|c|c|c|c|c|c|}
\hline \multicolumn{7}{|c|}{$\operatorname{Diet}(\mathrm{g} / \mathrm{kg})^{1}$} \\
\hline Parameter & MOLMO & MOLM25 & MOLM50 & MOLM100 & $\mathrm{SE}^{2}$ & P-value \\
\hline $\operatorname{RBC}\left(10^{12} / \mathrm{L}\right)$ & 2.84 & 2.77 & 2.96 & 2.86 & 0.067 & 0.317 \\
\hline Haematocrit (\%) & 27.3 & 26.8 & 28.4 & 27.7 & 0.568 & 0.251 \\
\hline Haemoglobin $(\mathrm{g} / \mathrm{L})$ & 9.12 & 9.47 & 9.20 & 9.63 & 0.368 & 0.741 \\
\hline $\mathrm{MCH}(\mathrm{pg})$ & 33.72 & 36.45 & 36.90 & 36.50 & 1.236 & 0.251 \\
\hline MCHC (\%) & 33.46 & 35.30 & 32.78 & 34.86 & 1.465 & 0.596 \\
\hline $\mathrm{WBC}\left(10^{9} / \mathrm{L}\right)$ & $8.52^{\mathrm{d}}$ & $9.46^{\mathrm{c}}$ & $10.1^{\mathrm{b}}$ & $11.1^{\mathrm{a}}$ & 0.127 & $<.0001$ \\
\hline Lymphocytes (\%) & $56.3^{\mathrm{a}}$ & $56.3^{\mathrm{a}}$ & $48.5^{\mathrm{b}}$ & $54.5^{\mathrm{a}}$ & 1.154 & 0.0013 \\
\hline Neutrophils (\%) & 21.9 & 19.9 & 25.9 & 28.8 & 2.979 & 0.204 \\
\hline Monocytes (\%) & $10.6^{\mathrm{a}}$ & $9.90^{\mathrm{a}}$ & $10.1^{\mathrm{a}}$ & $8.45^{\mathrm{b}}$ & 0.325 & 0.0034 \\
\hline Eosophils (\%) & $1.35^{\mathrm{c}}$ & $3.20^{\mathrm{a}}$ & $1.83^{\mathrm{b}}$ & $3.07^{\mathrm{a}}$ & 0.139 & $<.0001$ \\
\hline Basophils (\%) & $0.80^{\mathrm{a}}$ & $0.73^{\mathrm{ab}}$ & $0.70^{\mathrm{b}}$ & $0.62^{\mathrm{c}}$ & 0.025 & 0.0019 \\
\hline
\end{tabular}

ab In a row, lowercase superscripts compare strains within diet,

1Diet: MOLM0=broiler without MOLM inclusion; MOLM25= broiler finisher diluted with $25 \mathrm{~g}$ MOLM $/ \mathrm{kg}$; MOLM50= broiler finisher diluted with $50 \mathrm{~g}$ MOLM / kg; MOLM100= broiler finisher diluted at loo g MOLM $/ \mathrm{kg}$.

${ }^{2} \mathrm{SE}=$ Standard error

Table 3: Serum biochemical indices in 13-week old chickens fed incremental levels of Moringa oleifera leaf meal (MOLM)

\begin{tabular}{lllllll} 
& \multicolumn{7}{c}{ Diet $(\mathrm{g} / \mathbf{k g})$} \\
Parameter & MOLM0 & MOLM25 & MOLM50 & MOLM100 & SE & P-value \\
\hline Urea $(\mathrm{mmol} / \mathrm{L})$ & $0.52^{\mathrm{a}}$ & $0.47^{\mathrm{ab}}$ & $0.45^{\mathrm{b}}$ & $0.43^{\mathrm{b}}$ & 0.017 & 0.022 \\
Creatinine $(\mu \mathrm{mol} / \mathrm{L})$ & $10.0^{\mathrm{c}}$ & $11.5^{\mathrm{b}}$ & $11.3^{\mathrm{b}}$ & $12.0^{\mathrm{a}}$ & 0.083 & $<.0001$ \\
\hline Uric $(\mu \mathrm{mol} / \mathrm{L})$ & $279.3^{\mathrm{a}}$ & $247.4^{\mathrm{b}}$ & $218.7^{\mathrm{d}}$ & $231.3^{\mathrm{c}}$ & 0.892 & 0.0001 \\
\hline Total protein $(\mathrm{g} / \mathrm{L})$ & $40.0^{\mathrm{ab}}$ & $37.0^{\mathrm{b}}$ & $41.7^{\mathrm{a}}$ & $38.7^{\mathrm{ab}}$ & 1.118 & 0.065 \\
\hline Albumin $(\mathrm{g} / \mathrm{L})$ & $12.8^{\mathrm{a}}$ & $10.6^{\mathrm{b}}$ & $11.2^{2^{\mathrm{b}}}$ & $11.7^{\mathrm{ab}}$ & 0.399 & 0.084 \\
\hline Globulin $(\mathrm{g} / \mathrm{L})$ & 28.5 & 26.3 & 27.7 & 27.3 & 0.656 & 0.350 \\
\hline Cholesterol $(\mathrm{mmol} / \mathrm{L})$ & 2.71 & 2.94 & 2.93 & 2.89 & 0.169 & 0.739 \\
ALT $(\mathrm{U} / \mathrm{L})$ & 12.8 & 11.6 & 10.3 & 11.2 & 0.192 & 0.426 \\
\hline AST $(\mathrm{U} / \mathrm{L})$ & $132.0^{\mathrm{a}}$ & $131.5^{\mathrm{b}}$ & $126.8^{\mathrm{c}}$ & $122.1^{\mathrm{d}}$ & 0.148 & $<.0001$ \\
\hline ALKP $(\mathrm{U} / \mathrm{L})$ & $182.1^{\mathrm{a}}$ & $172.5^{\mathrm{b}}$ & $153.9^{\mathrm{d}}$ & $167.8^{\mathrm{c}}$ & 0.269 & $<.0001$
\end{tabular}

ab In a row, lowercase superscripts compare strains within diet,

1Diet: MOLM0=broiler without MOLM inclusion; MOLM25= broiler finisher diluted with $25 \mathrm{~g}$ MOLM $/ \mathrm{kg}$; MOLM50= broiler finisher diluted with $50 \mathrm{~g}$ MOLM / kg; MOLM100= broiler finisher diluted at $100 \mathrm{~g}$ MOLM/kg.

${ }^{2} \mathrm{SE}=\mathrm{Standard}$ error

Table 4: Effect of incremental levels MOLM on internal organs weight of 13 weeks chickens

\begin{tabular}{lllllll} 
Parameters & MOLM0 & MOLM25 & MOLM50 & MOLM100 & SE $^{\mathbf{2}}$ & Pvalue \\
\hline Heart & $7.33^{\mathrm{ab}}$ & $5.67^{\mathrm{b}}$ & $7.0^{\mathrm{ab}}$ & $7.83^{\mathrm{a}}$ & 0.315 & 0.076 \\
Liver & $16.83^{\mathrm{b}}$ & $19.17^{\mathrm{ab}}$ & $19.67^{\mathrm{ab}}$ & $21 . .50^{\mathrm{a}}$ & 0.006 & 0.839 \\
pancreas & $10.50^{\mathrm{a}}$ & $8.33^{\mathrm{b}}$ & $9.67^{\mathrm{a}}$ & $9.17^{\mathrm{a}}$ & 0.834 & 0.482 \\
Small intestine & $107.33^{\mathrm{b}}$ & $123.83^{\mathrm{ab}}$ & $125.67^{\mathrm{ab}}$ & $130.83^{\mathrm{a}}$ & 3.602 & 0.043 \\
Gizzard & $31.17^{\mathrm{b}}$ & $34.83^{\mathrm{b}}$ & $35.33^{\mathrm{ab}}$ & $42.67^{\mathrm{a}}$ & 2.069 & 0.117
\end{tabular}

ab In a row, lowercase superscripts compare strains within diet,

${ }^{1}$ Diet: MOLM0=broiler without MOLM inclusion; MOLM25= broiler finisher diluted with $25 \mathrm{~g} \mathrm{MOLM} / \mathrm{kg}$; MOLM50= broiler finisher diluted with $50 \mathrm{~g}$ MOLM / $\mathrm{kg}$; MOLM100= broiler finisher diluted at $100 \mathrm{~g}$ MOLM $/ \mathrm{kg}$.

2SE=Standard error

December 2019 | Volume 7 | Issue 12 | Page 1045 
protein, which resulted in optimal concentrations of blood constituents. The variation in immune response across the strains was expected due to their unique evolutionary history of individual strain domestication process and the distinctive selective pressures (Bilkovaa et al., 2017).

Moyo et al. (2011) and Sebola et al. (2017) reported that Moringa oleifera leaf contained (250, $5 \mathrm{dpm}, 490 \mathrm{mg} / \mathrm{kg}$ ) iron which may have resulted in higher iron intake, which promotes synthesis of haemoglobin and increases production of red blood cells within the permissible limit (Hurrell 1997; McDowell 2003). Incremental levels of MOLM exhibited higher WBC than control diet (MOLM0) (Table 2). Elevation of WBC within normal ranges with incremental levels of MOLM (MOLM100) will be beneficial to the animal in generating antibodies and developing immunity. Similarly, Gupta et al. (2010) reported a significant dose related increase in the WBC count and neutrophils in mice treated with Moringa oleifera extract. This reaction could be attributed to dietary phytochemicals with antioxidant properties such as flavonoids which are known to improve the immune system response in all taxa of vertebrates. Pakade et al. (2013) reported total flavonoids (21.15 mgQE/g) and phenolics (129.44 mgQE/g) concentrations in Moringa leaves. The dietary polyphenols not only stimulate the immune systems but also cause the modulations of detoxification enzymes, scavenging of oxidative agents and regulation of gene expression in cells (Catoni et al., 2008). When fed MOLM at incremental levels, PK and OV strains displayed lower lymphocytes compared to MOLM0, whilst no variation $(p>0.05)$ was observed in the BA chicken strain (Figure 1). Lower $(p<0.05)$ neutrophils were observed with MOLM incremental level in OV strain (Figure 2). Highest MOLM inclusion (MOLM100) resulted in higher eosinophils in both compared to MOLM0. Schalm et al. (1975) authored that white blood cells are defence cells of the body; their levels have a vast contribution in the immune responses and the ability of animals to fight infection. Higher WBC advantages birds with the ability to resist infection more than those with lower WBCs level.

Overall strain effect was shown in different types of white blood cells $(p<0.05)$. Several authors (Islam et al., 2004; Peters et al., 2011) reported differences in haematological parameters in African and Asian chicken. Chickens with functionally more heterophils may better bacterial infections and higher heterophils frequencies could, therefore, indicate stronger innate immune response (Bilkovaa et al., 2017)

Variations in plasma metabolites have been used as indicators of nutritional and health status in birds (Artacho et al., 2007; Rodríguez et al., 2005). Diet had a significant $(p>0.05)$ effect on serum urea, creatinine, uric acid,
AST and ALKP (Table 3). Diet x strain interaction did not $(p>0.05)$ affect total protein, globulin, cholesterol and ALT levels but significantly influenced Urea, Creatinine, albumin, Uric acid, AST and ALKP.

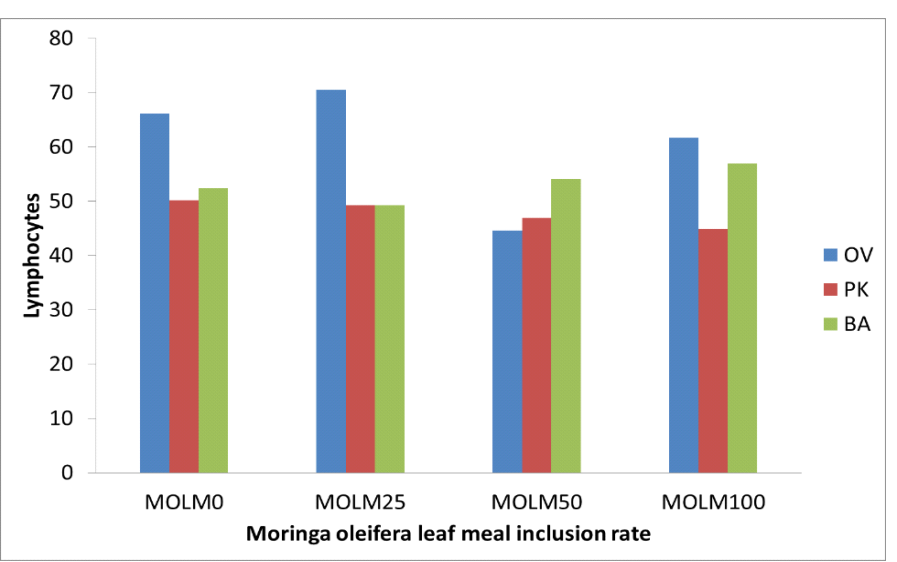

Figure 1: Lymphocytes (\%) of 3 strains of chickens fed incremental levels of Moringa oleifera leaf meal (0, 25, 50, and $100 \mathrm{~g} / \mathrm{kg}$ )

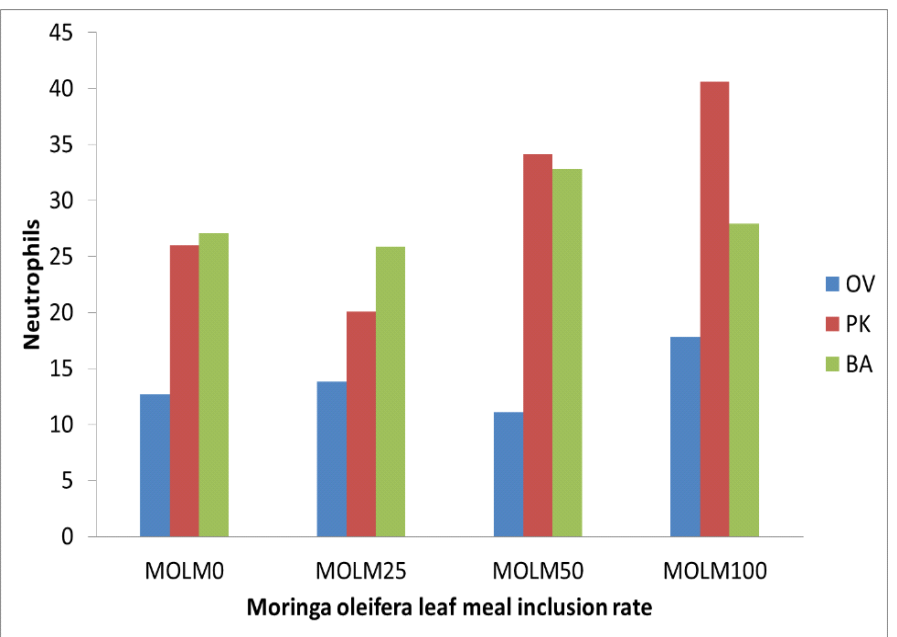

Figure 2: Neutrophils (\%) of 3 strains of chickens fed incremental levels of Moringa oleifera leaf meal (0, 25, 50, and $100 \mathrm{~g} / \mathrm{kg}$ )

Incremental levels of MOLM resulted in reduction of urea $(p<0.05)$. The fact that higher levels of MOLM inclusion reduced blood urea concentration may be an indication of better absorption and efficient utilization of dietary protein as compared to control diet (Table 3). In all chicken strains, incremental levels of MOLM resulted in higher $(p<0.05)$ creatinine content than when chickens were offered control diet. Total serum protein has been reported as an indication of protein retained in the body (Esonu et al., 2001), while total blood protein and creatinine contents have been shown to depend on the quantity and quality of dietary protein ingested (Awosanya et al., 1999; Esonu et al., 2001). Furthermore, Mune Mune et al. (2016) reported that M. oleifera leaf proteins resulted in $41.11 \%$ susceptibility to pepsin digestibility which makes it suitable for poultry utilisation. 
It is evident from the present findings that total serum differed among the strains. This is similar to the report of Ladokun et al. (2008) who reported a higher total serum protein in normally feathered compared to naked neck chickens. The lowest values of AST and ALKP were observed with incremental levels of MOLM. This indicates that MOLM had no toxic effect within the liver parenchyma of the birds thus resulting in improved immune response of the birds. Djuricic et al. (2011) also indicated that higher ALT and AST activities normally occur as a result of accelerated muscular tissue turnover and the elevated liver enzymes in the study are within normal ranges.

Strain and interaction (diet $\mathrm{x}$ strain) did not have a significant effect $(p>0.05)$ on internal organs weights. However, diet resulted significantly $(p<0.05)$ on small intestine length and gizzard weight (Table 4). Higher levels of MOLM resulted in longer intestinal length in all chicken strains. All chicken strains offered MOLM100 had the longest small intestines $(130.83 \mathrm{~cm})$ and heaviest gizzard weight $(42.67 \mathrm{~g})$. The improvement in gizzard weight and longer small intestine may be attributed to amino acids absorption and nutrients utilization of MOLM diets which resulted in better muscle development (Kokoszyński et al., 2017).

\section{CONCLUSION}

Moringa oleifera diet exhibited positive responses with different inclusion levels up to $100 \mathrm{~g} / \mathrm{kg}$ which had no adverse effect on haematological and serum biochemistry. It is, therefore, concluded that MOLM can be used as a feed supplement for different chicken strains without a risk of toxicity or compromised suboptimal nutritional status.

\section{ACKNOWLEDGMENTS}

This project was supported by Faculty Research Funds (North West University). Thanks to the Department of Animal Science (North West University) staff for support. The support received from Ms Lungisile Tshitshi in analysing blood samples is highly acknowledged.

\section{CONFLICT OF INTEREST}

The authors declare that they have no conflict of interest

\section{REFERENCES}

-Abbas ET (2013). The use of Moringa oleifera in poultry diets. Turkish J. Vet. Anim. Sci. 37: 492-496. https://doi. org/10.3906/vet-1211-40

-Artacho P, Soto-Gamboa M, Verdugo C, Nespolo RF (2007). Blood biochemistry reveals malnutrition in black-necked swans (Cygnusmelanocoryphus) living in a conservation priority area. Comparative Biochemistry and Physiology Part A: Molecular and Integrative Physiol. 146: 283-290. https://doi.org/10.1016/j.cbpa.2006.10.031

-Attia, YA, Al-Harthi MA (2015). Nigella seed oil as an alternative to antibiotic growth promoters for broiler Chickens. Eur. Poult. Sci. 79: 1-15.

-Attia YA, Tag El-Din, AE, Zeweil HS, Arafat MA (2003). Nutritional evaluation of nigella seed meal and the effect of microbial phytase and amino acids supplementations on its feeding value for Japanese Quai. In: Proceedings 9th Conference on Animal Nutrition. Hurghada, Egypt. p201217.9.

-Attia YA, El-Din AER, Zeweil HS, Hussein AS, Arafat MA (2008). The effect of supplementation of enzyme on laying and reproductive performance in Japanese Quail hens fed nigella seed meal. J. Poult. Sci. 45: 110-115. https://doi. org/10.2141/jpsa.45.110

-Awosanya BJK, Joseph DF, Ayoola MA (1999). Performance, blood chemistry and carcass quality attributes of rabbits. Int. Trop. J. Anim. Sci. 2: 89-96. https://doi.org/10.4314/tjas. v2i2.49687

-Bílkováa B, Bainováa Z. Janda J, Zita L, Vinklera M (2017). Different breeds, different blood: Cytometric analysis of whole blood cellular composition in chicken breeds. Vet. Immunol. Immunopathol. 188: 71-77. https://doi. org/10.1016/j.vetimm.2017.05.001

- Catoni C, Peters A, Schaefer HM (2008). Life history trade-offs are influenced by the diversity, availability and interactions of dietary antioxidants. Anim. Behav. 76: 1107-1119. https:// doi.org/10.1016/j.anbehav.2008.05.027

- Chen HL, Li DF, Chang BY, Gong LM, Daiand JG, Yi GF (2003). Effects of Chinese herbal polysaccharides on the immunity and growth performance of young broilers. Poult. Sci. https://doi.org/10.1093/ps/82.3.364

- Cowan MN (1999). Plant products as antimicrobial agents. Clin.Microbiol. Rev.12:564-582. https://doi.org/10.1128/ CMR.12.4.564

- Djuricic D, Dobranic T, Grizelj J, Gracner D, Harapin I, Stanin D, Folnozic I, Getz I, Cvitkovic D, Samardzija M (2011). Concentrations of total proteins and albumins, and AST, AP, CK and GGT activities in the blood serum Boer and Saanen goats during puerperium. Reprod.Domest.Anim. 46: 674677. https://doi.org/10.1111/j.1439-0531.2010.01726.x

-Essam SS, Rania TH, Amira A (2017). Prophylactic and immune modulatory influences of Nigella sativa Linn. in broilers exposed to biological challenge. Vet. World: 22310916

-Esonu BO, Emenalom O, Udedibie ABI, Herbert U, Ekpor CF, Okoli IC, heukwumere FC (2001). Performance and blood chemistry of weaner pigs fed raw Mucana bean (velvet) meal. Trop. Anim. Prod. 4: 49 - 54.

- Fallah R, Kianiand A, Azarfar A (2013). A review of the role of five kinds of alternatives to infeed antibiotics in broiler production. Vet. Med. Anim. Health. 5(11):317-321.

-Fuglie LJ (2001). The Miracle Tree: Moringa Oleifera: natural nutrition for the tropics. pp: 68. Revised in 2001 and published as The Miracle Tree: The Multiple Attributes of Moringa, pp: 172.

- Guo FC, Savelkoul HFJ, Kwakkel RP, Williams BA, Verstegen MWA (2004). Immunoactive, medicinal properties of mushroom and herb polysaccharides and their potential use in chicken diets. World's Poult. Sci. J. https://doi. 
org/10.1079/WPS20030026

- Gupta A, Khajuria A, Singh J, Bedi KL, Satti NK, Duff P, Suri KA, Suri OP, Qazi GN (2010). Immunomodulatory activity of biopolymeric fraction RLJ-NE-205 from Picrorhiza kurroa, Immunomodulatory effect of Moringa oleifera Lam. extract on cyclophosphamide induced toxicity in mice Inter Immunopharmacol. 6: 1543. https://doi.org/10.1016/j. intimp.2006.05.002

- Hurrell RF (1997). Bioavailability of iron. Eur. J. Clin. Nutr.51: S4-8. [PubMed] McDowell LR. 2nd ed. Amsterdam: Elsevier Science; 2003. Minerals Anim.Human Nutr.p. 660.

-Islam MS, Lucky NS, Islam MR, Ahad A, Das BR, Rahman MM, Siddiui MSI (2004). Haematological parameters of fayoumi, assil and local chickens reared in Sylhet region in Bangladesh. Int. J.Poult. Sci. 3: 144-147. https://doi. org/10.3923/ijps.2004.144.147

-Jain NC (1993). Essential of Veterinary Haematology, Lea \& Febiger, Philadelphia.

-Kokoszyński D, Bernacki Z, Saleh M, Stęczny K, Binkowska M (2017). Body Conformation and Internal Organs Characteristics of Different Commercial Broiler Lines. Brazilian J. Poult. Sci.19: 047-052. https://doi. org/10.1590/1806-9061-2016-0262

-Kondombo SR (2005). Improvement of village chicken production in a mixed (chicken-ram) farming system. PhD Thesis, Wageningen Institute of Animal Science, Wageningen University, The Netherlands.

-Ladokun AO, Yakubu A, Otite JR, Omeje JN, Sokunbi OA, Onyeji E (2008) Haematological and biochemical indices of naked neck and normally feathered Nigerian indigenous chickens in a sub humid tropical environment. Int. J. Poult. Sci. 7: 55-58. https://doi.org/10.3923/ijps.2008.55.58

- Litta G, Chung TK, Weber G M (2014). Vitamin E: vital for health and performance.

-McDowell LR (2003). 2nd ed. Amsterdam: Elsevier Science. Minerals Anim.Human Nutr. p. 660.

- Melesse A, Steingass H, Boguhn J, Rodehutscord M (2013). In vitro fermentation characteristics and effective utilisable crude protein in leaves and green pods of Moringa stenopetala and Moringa oleifera cultivated at low and mid-altitudes. J. Anim. Physiol. Anim. Nutr. 97: 537-546. https://doi. org/10.1111/j.1439-0396.2012.01294.x

- Moyo B, Masika PJ, Hugo A, Muchenje V (2011). Nutritional characterization of Moringa (Moringa oleifera Lam.) leaves. African J. Biotech. 10: 12925-12933. https://doi. org/10.5897/AJB10.1599

- Mune Mune MA, Bassogog CBB, Nyobe EC,Minka SR (2016). Physicochemical and functional properties of Moringa oleifera seed and leaf flour. Food Sci. Tech. 2: 1220352. https://doi.org/10.1080/23311932.2016.1220352

- Nworgu FC, Fasogbon FO (2007). Centrosema (Centrosema pubescens) leaf meal as protein supplement for pullet chicks and growing pullets. Int. J. Poult. Sci. 6: 255-260. https:// doi.org/10.3923/ijps.2007.255.260

-Pakade V, Cukrowska E, Chimuka L (2013). Metal and flavonol contents of Moringa oleifera grown in South Africa. S. Afr.J. Sci. 109: 01-07. https://doi.org/10.1590/sajs.2013/835

-Peters SO, Gunn HH, Imumorin IG, Agaviezor BO, Ikeobi CON (2011). Haematological studies on frizzled and naked neck genotypes of Nigerian native chickens. Trop. Anim. Health Prod. 43: 631-638. https://doi.org/10.1007/s11250010-9743-7

-Poultry (2014). Available from: http://www.worldpoultry.net/ Broilers Nutrition-1437326.

-Rodriguez P, Tortosa FS, Villafuerte R (2005). The effects of fasting underfeeding on biochemical parameters in the redlegged partridge (Alectorisrufa). Comparative Biochemistry and Physiology Part A: Molecular \& Integrative Physiol. 140: 157-164. https://doi.org/10.1016/j.cbpb.2004.11.014

-Schalm, OW, Jain, NC, Carrol EJ (1975). Veterinary Haematology. 3rd Edition, Lea and Febiger Publication, Philadelphia, 807-807.

-Sebola NA, Mlambo V, Mokoboki HK (2017). Chemical characterisation of Moringa oleifera leaves and apparent digestibility of the leaf meal-based diets in three chicken strains. Agrofor. Syst. https://doi.org/10.1007/s10457-0170074-9

-Sravanthi J, Rao SG (2014). Antioxidative studies in Moringa oleifera Lam. Annal. Phytomed. 3:101-105.

-SAS (2008). SAS User's Guide: Statistics, 9th edition. SAS Institute, Inc. Raleigh, North Caroline, USA.

- Tengerdy R P, Nockels CF (1976). Vitamin E or vitamin A protects chickens against E. coli infection. Poult. Sci. 54:1294-1296. https://doi.org/10.3382/ps.0541292

-WHO (2001) Traditional Medicines strategy (2002-2005) World Climate (2013): http://www.climate-charts.com/ Locations/n/NI65101.php.Retrieved 10/09/2013.

- Yasser JJ, Ali RA, Fateh OA (2014). Influence of adding garlic and thyme and their combination on immune response and some blood parameters in broiler. Int. J. Adv. Biol. Res. 4 (2): 211-215. https://doi.org/10.15192/PSCP. SA.2014.2.2.102106

-Windisch W, Kroismayr A (2006). The effect of phytobiotics on performance and gut function in monogastric. World nutrition forum: The future of animal nutrition, 85-90.

- Yang RY, Tsou SCS, Lee TC, Chang LC, Kuo G, Lai PY (2006). Moringa, a novel plant rich in antioxidants, bioavailable iron, and nutrients. Pp 224-239. In: C. T. Ho (ed) Challenges in Chemistry and Biology of Herbs. American Chemical Society, Washington, D.C. https://doi.org/10.1021/bk2006-0925.ch017 